\title{
The Effect of Varying Culture Conditions on the Production of Antibiotics by Streptomyces spp., Isolated from the Amazonian Soil
}

Ingrid Reis da Silva ${ }^{1,2 *}$, Mayra Kassawara Martins ${ }^{1}$, Clarice Maia Carvalho1, João Lúcio de Azevedo ${ }^{1,2}$ and Rudi Emerson de Lima Procópio ${ }^{1}$

${ }^{1}$ Microbiology Laboratory, Amazon Biotechnology Center - CBA, Manaus, Amazonas, Brazil

${ }^{2}$ Biotechnology, Federal University of Amazonas - UFAM, Manaus, Amazonas, Brazil.

\begin{abstract}
The genus Streptomyces is considered to be of great industrial importance because of its ability to produce secondary metabolites that account for $80 \%$ of the antibiotics currently in use. To optimise the production of antimicrobial compounds from three strains of Streptomyces spp. isolated from the Amazon's soil, we investigated the influence of physical (temperature, $\mathrm{pH}$, agitation and time) and chemical (concentrations of carbon and nitrogen) variables, according to a factorial statistical design consisting of three repetitions at the central point. During a period between five and twenty days of incubation, the temperature was varied between 20 and $40^{\circ} \mathrm{C}$, the pH was varied between 4.5 and 8.5 , and the agitation was varied between 100 and $300 \mathrm{rpm}$. The concentrations of carbon and nitrogen sources ranged from 5 to $15 \mathrm{~g} / \mathrm{L}$ and 0.5 to $1.5 \mathrm{~g} / \mathrm{L}$, respectively, and the results were evaluated using the Response Surface Methodology (RSM). Our data showed that the most effective carbon sources were starch and glycerol and that the best sources of nitrogen were phenylalanine, ammonia sulphate, asparagine and peptone. The results of this study showed that the temperature, incubation time and the culture medium directly influenced the production of metabolites (antibiotics). These parameters can be modified for the optimisation and improvement of the fermentation process by increasing the production of the compound of interest. Each Streptomyces behaved differently, requiring specific conditions for the production of secondary metabolites.
\end{abstract}

Keywords: Streptomyces; Antibiotic; Secondary metabolites

\section{Introduction}

Streptomyces spp. is a Gram-positive soil bacterium that grows as a vegetative mycelium with branching hyphae [1,2]. For dispersion, spores are formed on specialised reproductive structures called aerial hyphae, which emerge from the colony surface into the air [3]. Streptomycetes are renowned for their ability to produce clinically important antibiotics and other bioactive compounds. Recently, several studies were conducted to isolate new Streptomyces species from different habitats [4-6]. The biosynthesis of antibiotics is a specific property of microorganisms and depends on growth conditions. These microorganisms use a wide variety of substrates for growth; however, many of these substrates can have a negative effect on the production of some products of interest $[7,8]$. Under various nutrient limitations, the production of secondary metabolites is higher compared to non-limiting nutrient conditions [9]. Studies on the optimisation of antibiotic usually involve a search for ideal methods for their production. This is achieved by a systematic study of the adaptations of different physicochemical factors, such as nutrient limitation (carbon source, nitrogen source, and phosphate), oxygen, temperature, growth rate, feedback control, inactivation or induction [10]. The use of experimental factorial design and Response Surface Methodology (RSM) has been successfully applied in other fields, and it has been used to optimise media and culture conditions in some fermentation processes for the production of primary and secondary metabolites [11]. In the present study, we isolated Streptomyces from the Amazonian soil and determined the conditions for optimal antibiotic production.

\section{Materials and methods}

\section{Microorganisms}

The Streptomyces spp. were isolated from soil samples from the region of Manaus, Amazonas, Brazil. Pure cultures were grown in M9 medium (Sigma) plus starch $(10 \mathrm{~g} / \mathrm{L})$ and stored at $-70^{\circ} \mathrm{C}$ until needed.

\section{Evaluation of antimicrobial activity}

The antimicrobial activity was evaluated by agar diffusion well assays. The microorganism indicators used to evaluate the production of antibiotics were Staphylococcus aureus ATCC 25923, Streptococcus pneumoniae ATCC 49619, Enterococcus faecalis ATCC 29212, Escherichia coli ATCC 25922, Klebsiella pneumoniae ATCC 700603 and Staphylococcus aureus antibiotic resistant. The indicator microorganisms were plated on Mueller-Hington agar plates containing 5 orifices of $6 \mathrm{~mm}$, where $100 \mathrm{~mL}$ of filtrate from each Streptomyces isolate was placed in each well and standardised according to the McFarland scale (tube 0.5). The diameter of the zones of inhibition was measured after 16 hours of incubation at $37^{\circ} \mathrm{C}$.

\section{Identification of Isolates}

The identification of isolated strains was performed according to Bergey's Manual of Determinative Bacteriology [12]. Genomic DNA was extracted by a bead beating lysis method with $10 \%$ sodium dodecyl sulphate and phenol-chloroform. The 16S rRNA gene was amplified by PCR using the universal primers 27F (5'-GAGAGTTTGATCCTGGCTCAG-3') and 1401R (5’-CGGTGTGTACCCGGCCCGGAACG-3').

*Corresponding author: Ingrid Reis da Silva, Microbiology Laboratory, Amazon Biotechnology Center, CBA and Biotechnology, Federal University of Amazonas - UFAM, Manaus, Amazonas, Brazil, Tel: +55 92 31824862; E-mail: ingrid.cba@suframa.gov.br

Received July 19, 2012; Accepted July 26, 2012; Published July 28, 2012

Citation: da Silva IR, Martins MK, Carvalho CM, de Azevedo JL, de Lima Procópio RE (2012) The Effect of Varying Culture Conditions on the Production of Antibiotics by Streptomyces spp., Isolated from the Amazonian Soil. Ferment Technol 1:105. doi:10.4172/2167-7972.1000105

Copyright: (c) 2012 da Silva IR, et al. This is an open-access article distributed under the terms of the Creative Commons Attribution License, which permits unrestricted use, distribution, and reproduction in any medium, provided the original author and source are credited. 
The PCR conditions consisted of $95^{\circ} \mathrm{C}$ for 5 min followed by 30 cycles of $94^{\circ} \mathrm{C}$ for $1 \mathrm{~min}, 55^{\circ} \mathrm{C}$ for $1 \mathrm{~min}$, and $72^{\circ} \mathrm{C}$ for $1 \mathrm{~min} 30 \mathrm{~s}$, with a final step at $72^{\circ} \mathrm{C}$ for $10 \mathrm{~min}$. Subsequently, the DNA amplification product was purified (GFX PCR kit, Amersham Pharmacia Biotech) and sequenced. The partial $16 \mathrm{~S}$ rDNA sequence obtained was submitted to GenBank for BLAST searching, and phylogenetic analyses were conducted using the MEGA4 software program [13].

\section{Culture Media and Growth Conditions}

The following carbon sources were evaluated: corn starch, rice starch, glycerol, glucose and cellulose. To determine the best nitrogen source for antibiotic production, we assessed the following compounds: alanine, arginine, asparagine, cysteine, glycine, guanidine, glutamine, histidine, isoleucine, leucine, lysine, methionine, proline, phenylalanine, valine, tyrosine, aspartic acid, tryptophan, serine, threonine, yeast extract, malt extract, peptone, casein and ammonium sulphate. Streptomyces was grown for 7 days on medium containing AC-starch-casein [14]. The spores were then inoculated into a $500 \mathrm{~mL}$ Erlenmeyer flask containing $50 \mathrm{~mL}$ of liquid medium with a starchcasein composition (g/L). For the optimisation of antibiotic production, a pre-inoculum was used, whereby a volume of $2.5 \mathrm{~mL}$ of broth was inoculated into Erlenmeyer flasks $(250 \mathrm{~mL})$ containing $22.5 \mathrm{~mL}$ of production medium. As described below, carbon sources $(10.00 \mathrm{~g} / \mathrm{L})$, casein $(0.30 \mathrm{gL}), \mathrm{KNO}_{3}(2.00 \mathrm{~g} / \mathrm{L}), \mathrm{NaCl}(2.00 \mathrm{~g} / \mathrm{L}), \mathrm{K}_{2} \mathrm{HPO}_{4}(2.00 \mathrm{~g} / \mathrm{L})$, $\mathrm{KH}_{2} \mathrm{PO}_{4}(1.00 \mathrm{~g} / \mathrm{L}), \mathrm{CaCO}_{3}(0.10 \mathrm{~g} / \mathrm{L}), \mathrm{MgSO}_{4}(0.10 \mathrm{~g} / \mathrm{L}), \mathrm{FeSO}_{4}(0.01$ $\mathrm{g} / \mathrm{L}), \mathrm{ZnSO}_{4}(0.01 \mathrm{~g} / \mathrm{L})$, nitrogen sources $(1.00 \mathrm{~g} / \mathrm{L})$ and distilled water $(1$ $\mathrm{L}$ ) were mixed and the $\mathrm{pH}$ was adjusted to 6.5 . The flask was incubated at $28^{\circ} \mathrm{C}$ for two days. Using statistical design, the concentrations and conditions of the carbon and nitrogen sources were defined for the cultivation and production of antimicrobial compounds.

\section{Experimental Design}

A statistical factorial design was conducted by the RSM with three replicates at the central point for building the statistical model by MINITAB. Twenty-seven experiments were performed where the isolates were grown in liquid culture medium under different conditions of $\mathrm{pH}$, agitation, temperature and rise time. The $\mathrm{pH}$ was varied from 4.5 to 8.5 , stirring was varied between 100 to $300 \mathrm{rpm}$, temperature was varied between 20 to $40^{\circ} \mathrm{C}$ and incubation time was varied between 5 to 20 days. To determine the optimal conditions for improving the production of antimicrobial metabolites, we performed another statistical design, as described above using the RSM. We evaluated the influence of two carbon sources (starch and glycerol) and four sources of nitrogen (phenylalanine, asparagine, peptone and ammonium sulphate). The concentrations of starch and glycerol ranged from 5 to $15 \mathrm{~g} / \mathrm{L}$ and nitrogen varied from 0.5 to $1.5 \mathrm{~g} / \mathrm{L}$. This resulted in 27 media formulations from different cultures, each corresponding to an experimental test.

\section{Results and Discussion}

\section{Antimicrobial activity}

Using the methodology described, 371 Streptomyces were isolated from the soil in the region of Manaus, Amazonas, Brazil. The antimicrobial activity for all 371 isolates on solid medium by the agar diffusion method was determined. The predominant antimicrobial activity was against Gram-positive bacteria (46 isolates), and only five isolates had activity against Gram-negative bacteria. Table 1 shows the isolates exhibiting antimicrobial activity against microorganisms. There was a high rate of inhibition of Gram-positive bacteria by antibiotics produced by Streptomyces. Low activity against Gram-negative bacteria may be due to the complexity of the outer membrane of these bacteria $[15,16]$.

Only five isolates exhibited activity, under the conditions tested, against Gram-negative bacteria (Escherichia coli ATCC25922, Klebsiella pneumoniae ATCC700603). In most cases the antimicrobial activity was detected against the Gram-positive bacteria (Staphylococcus aureus ATCC25923, ATCC49619 Streptococcus pneumoniae, Enterococcus faecalis ATCC29212). All three (01, 325 and 355) isolates selected demonstrated activity against antibiotic-resistant Staphylococcus aureus (erythromycin, penicillin, gentamicin, oxacillin, cefotaxime, cefoxitin, norfloxacin, ceftriaxone, aztreonam, cephalothin, amikacin, clindamycin, tobramycin and ceftazidima). Among the pathogens, Staphylococcus aureus represents one of the main agents of nosocomial infection. Because $S$. aureus is difficult to control with antibiotics, spreads easily and causes high mortality rates, there is a need to develop new compounds for therapeutic treatment against infections caused by these bacteria. It was found that a Streptomyces spp. isolated from marine sediment that showed activity against Staphylococcus aureus (MRSA) [17]

\section{Molecular characterisation of Streptomyces}

Using the 16S rRNA gene of three Streptomyces (01, 325 and 355), in this study it was possible to identify and evaluate the similarity with other strains at the National Center for Biotechnology Information (NCBI). Considering the importance of Streptomyces in biological terms, the production of secondary metabolites and adaptation to the environment is important in understanding its relationship to other species and the diversity within this genus. This indicates that the chemical diversity is associated with the biological diversity of complex microbial communities and is distributed heterogeneously [18]. The three strains studied did not form a single phylogenetic group, as seen in Figure 1. Despite the differences between the Streptomyces spp.,

\begin{tabular}{|c|c|c|c|c|c|}
\hline \multirow{2}{*}{ Isolates } & \multicolumn{5}{|c|}{ Pathogens } \\
\hline & $S$ aureus & S pneumoniae & E faecalis & K pneumoniae & E coli \\
\hline $\begin{array}{l}N^{\circ} 01,315,325, \\
355,234\end{array}$ & +++ & +++ & +++ & - & - \\
\hline$N \circ 166$ & +++ & ++ & ++ & - & - \\
\hline$N^{\circ} 279$ & +++ & - & +++ & + & - \\
\hline$N^{0} 121,167,282$ & +++ & - & +++ & - & - \\
\hline$N^{0} 371$ & +++ & ++ & - & - & - \\
\hline$N^{0} 107,305,372$ & +++ & - & - & - & - \\
\hline $\begin{array}{l}\mathrm{N}^{\circ} 129,184, \\
189,, 252\end{array}$ & - & - & +++ & - & - \\
\hline $\begin{array}{l}N^{0} 168,204, \\
210,211,343, \\
353,356,357, \\
358,361\end{array}$ & - & +++ & - & - & - \\
\hline$N^{\circ} 335,379$ & ++ & - & ++ & - & - \\
\hline$N^{0} 113$ & - & - & - & - & ++ \\
\hline $\begin{array}{l}N^{0} 181,256, \\
265,294\end{array}$ & - & - & - & ++ & - \\
\hline $\begin{array}{l}N^{\circ} 02,81,84, \\
365,376\end{array}$ & ++ & - & - & - & - \\
\hline$N^{\circ} 359$ & - & ++ & - & - & - \\
\hline $\begin{array}{l}N^{0} 377,383, \\
392,393,394\end{array}$ & + & - & - & - & - \\
\hline
\end{tabular}

Low (+): inhibition zone diameter between 07 and $12 \mathrm{~cm}$;

Moderate $(++)$ : inhibition zone diameter between 13 and $16 \mathrm{~cm}$;

High $(+++)$ : inhibition zone diameter greater than $17 \mathrm{~cm}$;

Neg (-): no inhibition zone

Table 1: Classification of antimicrobial activity displayed by Streptomyces 
the similarity is high $(0.005$, or less than $1 \%)$, which is common for this genus [19]. There remains the difficulty of finding patterns in the sequences and strains in most studies that describe the strain as Streptomyces spp. [20,21]. Using only the $16 \mathrm{~S}$ rRNA sequence, it is almost impossible to identify the level of a Streptomyces species, six strains of $S$. hygroscopicus evaluated were unable to form a group using the phylogenetic $16 \mathrm{~S}$ rRNA [18]. Other authors suggest that the $16 \mathrm{~S}$ rRNA gene is an important tool for phylogenetic analysis of Gramnegative bacteria but not for Streptomyces [19]. Despite the difficulty in classifying each strain to the species level using the 16S rRNA gene, all three strains were confirmed to belong to the genus Streptomyces.

\section{Optimisation of production conditions}

Development of efficient fermentation processes for the production of secondary metabolites by Streptomyces requires examination of a diverse array of species-specific features, including physical and chemical factors. Carbohydrates and nitrogen play key roles as structural and energy compounds in cells. Thus, to determine the optimal medium for antibiotic production, various carbon and nitrogen sources were tested. The results showed that the most effective carbon sources were starch and glycerol, and the best sources of nitrogen were phenylalanine, ammonia sulphate, asparagine and peptone [22]. Therefore, these compounds were chosen for the subsequent optimisation study. Although cultures of S. noursei ATCC 11455 supplied with glucose as a carbon source achieved high nystatin titres, due to the high biomass concentration, glucose tended to negatively influence the production of nystatin, independent of specific growth rates when phosphate and ammonium were in excess. Glycerol was a better carbon source than glucose, yielding higher nystatin production. Several studies have been performed cultivating Streptomyces under different growth conditions, such as fermentation liquid and solid, static culture or under agitation, to optimise the production of antibiotics. These studies demonstrate the significant influence of external conditions on the biosynthesis of these compounds [23]. In (Table 2), the optimal physical conditions for the production of antimicrobial compounds by each isolate are shown. Values demarcated with an (s) were statistically significant, with a confidence level of $95 \%$ or $\mathrm{p}$ value $=0.05$.

Statistical analysis showed that varying the time had a significant effect on the production of the antimicrobial compounds produced by strain No. 01 . The antimicrobial compound produced by isolate No. 01 showed the largest inhibition zones and highest stability when exposed to different growth conditions. The production of its antimicrobial compound was observed on the first day of cultivation. Cultivation temperature generally affects metabolite biosynthesis. In this study, the change in temperature was only significant for strain No. 325, based on the diameter of the inhibition zone, the production of this antimicrobial agent was greatest at $30^{\circ} \mathrm{C}$. Temperature and soybean flour concentration were shown to be the two most important variables that affect the production of clavulanic acid, at a $95 \%$ confidence level [24]. Validamycin-A biosynthesis by S. hygroscopicus 5008 was investigated between $28^{\circ} \mathrm{C}$ and $42^{\circ} \mathrm{C}$. An interesting threshold of temperature for biosynthesis was found between $35^{\circ} \mathrm{C}$ and $37^{\circ} \mathrm{C}$ [25].

The significant variables for isolate No. 355 were time and $\mathrm{pH}$. The production of the antimicrobial compound was greatest after incubation for about 10 to 15 days at $\mathrm{pHs}$ between 7-8.5. The production of antimicrobial compounds also significantly change in response to the carbon source in the culture growth medium. Table 3 illustrates the ideal nutritional conditions for each isolate. Values with an (s) were statistically significant with a confidence level of $95 \%$ or $p$ value $=0.05$.
The three independent variables of concentration of the carbon source (glucose), nitrogen source (soybean meal) and temperature of incubation were found to be the most important for the production of antifungal antibiotics by the $S$. chattanoogensis MTCC 3423 isolate. The optimal combination of the three factors for a maximum yield (263.63 $\mathrm{U}$ ) of the antibiotic was $5 \%$ glucose (carbon source), $1 \%$ soybean meal (nitrogen source) and an incubation temperature of $30^{\circ} \mathrm{C}[26]$.

For isolate No.01, according to the diameter of the inhibition zone, the production of the antimicrobial compound was greater when the microorganism was grown in glycerol rather than in starch. Similar results were reported [27], who employed the RSM to optimise the composition of the medium for the production of avermectin B1a by Streptomyces avermitilis 14-12A. Corn starch and yeast extract were significant variables, yielding maximum values of production with $149.57 \mathrm{~g} / \mathrm{L}$ of corn starch and $8.92 \mathrm{~g} / \mathrm{L}$ of extract yeast. Yeast extract

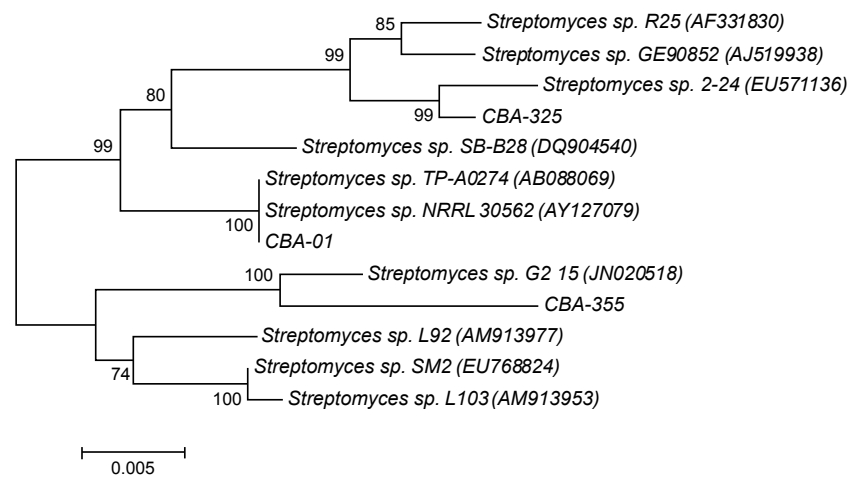

Figure 1: Phylogeny showing relationships between Streptomyces, based on clustering of the sequences of the 16S rRNA gene (coefficient of Neighbourjoining) The software package MEGA 4 was used for analysis.

\begin{tabular}{|c|c|c|c|c|}
\hline Isolates & Temperature & Time & $\mathbf{p H}$ & Agitation \\
\hline intervals & 20 to $40^{\circ} \mathrm{C}$ & 1 to 20 days & 4,5 to 8,5 & 100 to $300 \mathrm{rpm}$ \\
\hline $\mathbf{0 1}$ & $\begin{array}{c}20 \text { to } 35^{\circ} \mathrm{C} \\
\text { (ns) }\end{array}$ & $\begin{array}{c}10 \text { to } 20 \text { days } \\
\text { (s) }\end{array}$ & $\begin{array}{c}6,5 \text { to } 7,5 \\
\text { (ns) }\end{array}$ & $\begin{array}{c}150 \text { to } 200 \\
\text { (ns) }\end{array}$ \\
\hline 325 & $\begin{array}{c}30^{\circ} \mathrm{C} \\
\text { (s) }\end{array}$ & $\begin{array}{c}10 \text { days } \\
\text { (ns) }\end{array}$ & $\begin{array}{c}6,5 \\
\text { (ns) }\end{array}$ & $\begin{array}{c}100 \text { to } 200 \\
\text { (ns) }\end{array}$ \\
\hline 355 & $\begin{array}{c}25^{\circ} \mathrm{C} \\
\text { (ns) }\end{array}$ & $\begin{array}{c}15 \text { days } \\
\text { (s) }\end{array}$ & $\begin{array}{c}7,5 \\
\text { (s) }\end{array}$ & $\begin{array}{c}150 \\
\text { (ns) }\end{array}$ \\
\hline
\end{tabular}

(ns): not significant

(s): significant at the level of $95 \%$

Table 2: Improved physical conditions for the production of antimicrobial compounds using isolates No 01, 325 and 355.

\begin{tabular}{|c|c|c|c|c|c|}
\hline Isolates & $\begin{array}{c}\text { Source of } \\
\text { nitrogen }\end{array}$ & Starch & $\begin{array}{c}\text { Source of } \\
\text { nitrogen } \\
\text { and starch }\end{array}$ & Glycerol & $\begin{array}{c}\text { Source of } \\
\text { nitrogen and } \\
\text { glycerol }\end{array}$ \\
\hline Intervals & $\begin{array}{c}20 \text { Amino } \\
\text { Acids }\end{array}$ & 5 to $15 \mathrm{~g}$ & 0,5 to $1,5 \mathrm{~g}$ & 5 to $15 \mathrm{~g}$ & 0,5 to $1,5 \mathrm{~g}$ \\
\hline $\mathbf{0 1}$ & $\begin{array}{c}\text { Phenylalanine } \\
\text { and Sulf } \\
\text { ammonium }\end{array}$ & $\begin{array}{c}12,5 \text { to } 15 \\
\mathrm{~g} \mathbf{( s )}\end{array}$ & $\begin{array}{c}1 \text { to } 1,25 \mathrm{~g} \\
\text { (ns) }\end{array}$ & $\begin{array}{c}\text { Minor } \\
\text { Production }\end{array}$ & Minor Production \\
\hline $\mathbf{3 2 5}$ & $\begin{array}{c}\text { Phenylalanine } \\
\text { and Sulf } \\
\text { ammonium }\end{array}$ & $\begin{array}{c}\text { Minor } \\
\text { Production }\end{array}$ & $\begin{array}{c}\text { Minor } \\
\text { Production }\end{array}$ & $\begin{array}{c}7,5 \mathrm{~g} \\
\text { (ns) }\end{array}$ & $\begin{array}{c}1,25 \mathrm{~g} \\
\text { (s) }\end{array}$ \\
\hline $\mathbf{3 5 5}$ & $\begin{array}{c}\text { Asparagine } \\
\text { peptone }\end{array}$ & $\begin{array}{c}7,5 \mathrm{~g} \\
\text { (ns) }\end{array}$ & $\begin{array}{c}0,75 \mathrm{~g} \\
\text { (ns) }\end{array}$ & $\begin{array}{c}\text { No } \\
\text { production }\end{array}$ & No production \\
\hline
\end{tabular}

(ns): Not significant

(s): A significant $95 \%$

Table 3: Nutritional conditions ideal for the production of the antimicrobia compound using isolate No 01,325 and 355. 
Citation: da Silva IR, Martins MK, Carvalho CM, de Azevedo JL, de Lima Procópio RE (2012) The Effect of Varying Culture Conditions on the Production of Antibiotics by Streptomyces spp., Isolated from the Amazonian Soil. Ferment Technol 1:105. doi:10.4172/2167-7972.1000105

increased the mycelium biosynthesis but did not affect the growth rate [28].

The production of antimicrobial compounds by strain No. 325 was higher when the organism was cultured in medium with glycerol as the carbon source. The variable inorganic nitrogen (ammonium sulphate) was only significant for trials with glycerol. Nutrition plays an important role in the onset and intensity of secondary metabolism. Control of antibiotics biosynthesis was demonstrated to be a multifunctional process in which limiting nutrients, such as nitrogen, affects the metabolism [29]. The best conditions for isolate No. 355 were established by adjusting the physical variables (Table 2). Supplementing the culture media to enhance antimicrobial activity did not alter the production. The nitrogen sources usually favourable to growth, such as ammonium salts in nonlimiting amounts, repress the enzymes involved in the assimilation of other nitrogen sources such as amino acids with an inhibitory effect on the secondary metabolism[30].

The results of this study showed that the temperature, incubation time and the culture medium directly influence the production of metabolites (antibiotics). These parameters can be modified for the optimisation and improvement of the fermentation process by increasing the production of the compound of interest. It is important to establish a mathematical relationship among the medium components and length of incubation period for achieving maximum antibiotic yield [31]. The three strains tested here behaved differently, with each Streptomyces spp. requiring specific conditions for the production of secondary metabolites. The three selected isolates have the potential for producing antibiotics that are able to inhibit many clinically important strains, such as Staphylococcus aureus (MRSA). These Streptomyces strains may be studied in the future to discover new and more effective antibiotics.

\section{Acknowledgements}

Financial support: This work was supported by the Fundação de Amparo a Pesquisa do Estado Amazonas (FAPEAM) and the Centro de Biotecnologia da Amazônia (CBA).

Brusic V, Rudy G, Honeyman G, Hammer J, Harrison L (1998) Prediction of $\mathrm{MHC}$ class II- binding peptides using an evolutionary algorithm and artificial neural network. Bioinformatics 14: 121-130.

\section{References}

1. Embley TM, Stackebrandt E (1994) The molecular phylogeny and systematics of the actinomycetes. Annu Rev Microbiol 48: 257-289.

2. González I, Ayuso-Sacido A, Anderson A, Genilloud O (2005) Actinomycetes isolated from lichens: Evaluation of their diversity and detection of biosynthetic gene sequences. FEMS Microbiol Ecol 54: 401-415.

3. Madigan MT, Martinko JM, Parker J (2000) Brock Biology of Microorganisms (9thedn) Upper Saddle River, Prentice Hall.

4. Mansour SR (2003) The occurrence and distribution of soil actinomycetes in Saint Catherine area, South Sinai, Egypt. Pakistan J Biol Sci 6: 721-728.

5. Chater KF (2006) Streptomyces inside-out: a new perspective on the bactéria that provide us with antibiotics. Philos Trans R Soc Lond B Biol Sci 361: 761 768.

6. Bon EPS, Ferrara MA, Corvo ML (2008) Enzimas em Biotecnologia Rio de Janeiro. Ed Interciencia 71-94.

7. Yoon YJ, Choi CY (1997) Nutrient effects on FK-506, a new immunosuppressant, production by Streptomyces sp in a defined medium. J Ferment Bioeng 83 599-603.

8. Zeng AP, Deckwer WD (1995) A kinetic model for substrate and energy consumption of microbial growth under substrate-sufficient conditions. Biotechnol Prog 11: 71-79.

9. Reddy NG, Ramakrishna DPN, Rajagopal SV (2011) Optimization of culture conditions of Streptomyces rochei (MTCC 10109) for the production of antimicrobial metabolites. Egypt J Biol 13: 21-29.

10. Salamoni SP (2010) Avaliação da atividade antimicrobiana de isolados de Streptomyces e estudo de produção de moléculas bioativas 2010 Porto Alegre: UFRGS Tese (Doutorado em microbiologia agrícola e do ambiente) Universidade Federal do Rio Grande do Sul Porto Alegre.

11. Adinarayana K, Ellaiah P, Srinivasulu B, Devi RB, Adinarayana G (2003) Response surface methodological approach to optimize the nutritional parameters for neomycin production by Streptomyces marinensis under solidstate fermentation. Process Biochem 38: 1565-1572.

12. Bergey DH, Holt JG, Krieg NR (1994) Bergey's Manual of Determinative Bacteriology (9thedn), Williams and Wilkins, Baltimore, USA.

13. Tamura K, Dudley J, Nei M, Kumar S (2007) MEGA4: Molecular Evolutionary Genetics Analysis (MEGA) software version 4.0. Mol Biol Evol 24: 1596-1599.

14. Kuester E, Williams ST (1964) Selection of media for isolation of streptomycetes. Nature 202: 928-929.

15. Heck M G (2007) Produção de compostos antimicrobianos provenientes do metabolismo de Streptomyces sp Linhagem 2S 2007 Porto Alegre: UFRGS Dissertação (Mestrado em microbiologia agrícola e do ambiente), Universidade Federal do RS, Porto Alegre.

16. Duarte MW (2009) Atividade antimicrobial and produção of extracellula enzymes by actinomycetes often isolated in Porto Alegre only: UFRGS TCC (Bacharelado em Ciências Biológicas) Universidade Federal do Rio Grande do Sul Porto Alegre.

17. Shin HJ, Lee HS, Lee DS (2010) The Synergistic Antibacterial Activity of 1-Acetyl- $\beta$-Carboline and beta-Lactams against Methicillin-Resistant Staphylococcus aureus (MRSA). J Microbiol Biotechnol 20: 501-505.

18. Kumar Y, Goodfellow M (2010) Reclassification of Streptomyces hygroscopicus strains as Streptomyces aldersoniae sp. Nov., Streptomyces angustmyceticus sp. Nov., comb. Nov., Streptomyces ascomycinicus sp. Nov., Streptomyces decoyicus sp. Nov., comb. Nov., Streptomyces milbemycinicus sp. Nov. and Streptomyces wellingtoniae sp. nov. Int J Syst Evol Micr 60: 769-775.

19. Song J, Lee SC, Kang JW, Baek HJ, Suh JW (2004) Phylogenetic analysis of Streptomyces spp Isolated from potato scab lesions in Korea on the basis of 16S rRNA gene and 16S -23S rDNA internally transcribed spacer sequences. Int J Syst Evol Microbiol 60: 203-209.

20. Kurosawa K, Bui VP, VanEssendelft JL, Willis LB, Lessard PA, et al. (2006) Characterization of Streptomyces MITKK-103, a newly isolated actinomycin X2-producer. Appl Microbiol Biotechnol 72: 145-154.

21. O’Neill B, Grossman J, Tsai MT, Gomes JE, Lehmann J, et al. (2009) Bacteria community composition in Brazilian Anthrosols and adjacent soils characterized using culturing and molecular identification. J Microb Ecol 58: 23-35.

22. Jonsbu E, Mcintyre M, Nielsen J (2002) The influence of carbon sources and morphology on nystatin production by Streptomyces noursei J Biotechnol 95 133-144.

23. Hassan MA, El-Naggar MY, Said WY (2001) Physiological factors affecting the production of a antimicrobial substance by Streptomyces violatus in batch cultures. Egypt J Biol 3: 1-10.

24. Viana DA, Carneiro-Cunha MN, Araújo JM, Barros-Neto B, Lima-Filho JL, et al. (2010) Screening of Variables Influencing the Clavulanic Acid Production by Streptomyces DAUFPE 3060 Strain. Appl Biochem Biotechnol 160: 17971807.

25. Liao Y, Wei ZH, Bai L, Deng Z, Zhong JJ (2009) Effect of fermentation temperature on validamycin A production by Streptomyces hygroscopicus 5008. J Biotechnol 142: 271-274.

26. Gupte MD, Kulkarni PR (2002) A study of antifungal antibiotic production by Streptomyces chattanoogensis MTCC 3423 using full factorial design. Lett Appl Microbiol 35: 22-26.

27. Hong G, Mei L, Jintao L, Huanqin D, Xianlong Z, et al. (2009) Medium optimization for the production of avermectin B1a by Streptomyces avermitilis 14-12A using response surface methodology. Bioresour Technol 100: 4012 4016.

28. Suutari M, Lignell U, Hyvärinen A, Nevalainen A (2002) Media for cultivation of indoor streptomycetes. J Microbiol Methods 51: 411-416.

29. Feng WH, Mao XM, Liu ZH, Li YQ (2011) The ECF sigma factor SigT regulates 
Citation: da Silva IR, Martins MK, Carvalho CM, de Azevedo JL, de Lima Procópio RE (2012) The Effect of Varying Culture Conditions on the Production of Antibiotics by Streptomyces spp., Isolated from the Amazonian Soil. Ferment Technol 1:105. doi:10.4172/2167-7972.1000105

Page 5 of 5

actinorhodin production in response to nitrogen stress in Streptomyces coelicolor. Appl Microbiol Biotechnol 92: 1009-1021.

30. Inoue OO (2006) Influência de diferentes limitações nutricionais sobre a produção de Retamicina por Streptomyces olindensis ICB 20. São Paulo: EPSP Tese (Doutorado em Engenharia) Escola Politécnica de São Paulo, São Paulo.
31. Tripathi CK, Khan M, Praveen V, Khan S, Srivastava A (2012) Enhanced antibiotic production by Streptomyces sindenensis using artificial neural networks coupled with Genetic Algorithm and Nelder-Mead Downhill Simplex. J Microbiol Biotechnol 22: 939-946. 